25. Юдин А.И. Варфоломеевская стоянка и неолит степного Поволжья. Саратов: Изд-во Сарат. унта, 2004. $200 \mathrm{c}$.

26. Барацков А.В., Выборнов А.А., Юдин А.И., Васильева И.Н., Кулькова М.А., Косинцев П.А., Гослар Т., Филиппсен Б. Новая стоянка степного неолита Алгай: материалы междунар. науч. конф. 2427 мая 2016 года / отв. ред. О.В. Лозовская, А.Н. Мазуркевич, Е.В. Долбунова. СПб.: ИИМК РАН, 2016. С. $49-51$.

27. Юдин А.И., Выборнов А.А., Барацков А.В. Неолитическая стоянка Алгай в степном Волго-Уральс- ком междуречье // V (XXI) всерос. археологический съезд. Барнаул, 2017. С. 1199-1200.

28. Выборнов А.А., Юдин А.И., Кулькова М.А., Гослар Т., Посснерт Г., Филиппсен Б. Радиоуглеродные данные для хронологии неолита Нижнего Поволжья // Радиоуглеродная хронология эпохи неолита Восточной Европы VII-III тысячелетия до н.э. Смоленск: Свиток, 2016. С. 62-74.

Работа подготовлена в рамках выполнения Государственного задания Минобрнауки РФ, проект № 33. 1907.2017/ПЧ «Традиционные и инновационные модели развития древнего населения Поволжья».

\title{
COMPARISON OF GEOMETRIC MICROLITHS OF THE NORTHERN CASPIAN AND LOWER DON
}

(C) 2018

\author{
Smagin Valery Andreevich, master student of Domestic History and Archeology Department \\ Samara State University of Social Sciences and Education (Samara, Russian Federation)
}

Abstract. Geometric microliths are inherent in almost all the Mesolithic and Neolithic monuments in the Lower Volga Region. For the sites of the territory they play a key role. With the help of this type of tools, it is possible to determine the cultural affiliation and chronological position of the studied monuments. In this paper we mainly consider the Neolithic sites on the territory of the Lower Volga and Lower Donets, which have geometric microliths in stone implements. Most of these monuments have a fairly stable series of tools of a geometric type, which makes it possible to compare them among themselves and draw parallels. The results of radiocarbon dating for Neolithic monuments of the Lower Volga and Lower Donets are presented. There is a typological comparison of these sites. The paper discusses similarities and differences, as well as possible contacts, or the lack of population on the two territories - the Lower Volga and the Lower Donets. The author comes to the conclusion that based on the analysis of geometric microliths it is not possible to trace a significant connection between the population of the Lower Volga and the Lower Donets. In the development of the flint industries of these regions there are more differences than similarities.

Keywords: Lower Volga Region; Lower Don; Mesolithic; Neolithic; radiocarbon chronology; Traceology; typology; Kairshak-Tentorsor group of monuments; Rakushechniy Yar culture; stone inventory; geometric microliths; trapezoid with planed back; segment; parallelogram; retouch.

\section{ПОЧВЕННО-АРХЕОЛОГИЧЕСКАЯ ХАРАКТЕРИСТИКА ПОСЕЛЕНИЯ КАЛМЫКОВКА І В САМАРСКОМ ПОВОЛЖЬЕ}

\author{
Овчинников Андрей Юрьевич, кандидат биологических наук, \\ старший научный сотрудник лаборатории экологии почв \\ Институт физико-химических и биологических проблем почвоведения РАН \\ (2. Пушиино, Московская область, Российская Федерация) \\ Андреев Константин Михайлович, кандидат исторических наук, \\ доцент кафедры отечественной истории и археологии \\ Самарский государственный сочиально-педагогический университет (г. Самара, Российская Федераиия)
}

Аннотация. В статье публикуются результаты проведенных почвенных исследований на памятнике археологии - поселении эпохи неолита и бронзы Калмыковка I, расположенном в Красноярском районе Самарской области. В статье приводится краткая характеристика археологического объекта. Обозначается его культурная принадлежность и абсолютный возраст обнаруженных артефактов. На ключевом участке выполнены морфологические исследования, проведен анализ физических и химических свойств современных почв, почвообразующих пород и культурных археологических слоев. Выявлено таксономическое различие почв, связанное с антропогенной преобразованностью почвы в среднем и позднем голоцене. Выявлено изменение физических свойств почв от водораздела к речным террасам. Подобная закономерность зафиксирована на других археологических объектах в Среднем Поволжье. Меандрирование русел и изменение уровня рек в разные временные интервалы голоцена приводило к изменению гранулометрического состава прирусловых и притеррасных территорий. Предварительные результаты показали, что при организации поселения Калмыковка I древним человеком в разные эпохи голоцена учитывались: география территории, ландшафт, русло реки. Изменение палеогеографической обстановки на данной территории от среднего голоцена к позднему, видимо, влияло на полноводность реки Сок и ее русло, что вынуждало последующие поколения людей переносить стоянку вглубь водораздельной поверхности.

Ключевые слова: почвоведение; археология; палеопочвоведение; палеогеография; палеоэкология; стратиграфия; археологическое поселение; культурный слой; почвообразование; почвенный профиль; морфология почв; физико-химические свойства почв; голоцен; неолит; средневолжская культура; эпоха поздней бронзы; срубная культура; абсолютная хронология; Среднее Поволжье. 


\section{Введение}

Современное функционирование и генезис почв являются наиболее значимыми проблемами в современном почвоведении и палеопочвоведении. Почвы зачастую сохраняют и отображают признаки эволюции и изменения окружающей среды как во времени, так и в пространстве. Почва является хранилищем артефактов разных времен и различных культур. Анализ многочисленных почвенных признаков и особенностей стратиграфии почвенных профилей является важным в интерпретации данных для многих смежных научных дисциплин, где почвы выступают одним объектом исследования. Знать историю формирования современных почв очень важно, так как ее особенности и свойства отражают в себе происходившие климатические изменения, изменение в биосфере, а с ними и развитие человечества.

Многочисленные данные разных естественнонаучных дисциплин показывают, что почвообразующие породы центра Восточно-Европейской равнины, выступающие «фундаментом» для современных почв, формировались в условиях единой широтной гиперзоны. Дифференциация природных условий существовала в основном на региональном и локальном уровнях [1-4]. В настоящее время все же остаются некоторые нерешенные вопросы, затрудняя возможность точной реконструкции состояния природной среды. К настоящему моменту в почвоведении наблюдается ограниченность подхода к почвам только как к продукту наблюдаемых факторов. Достигнутый в последние десятилетия прогресс в познании истории развития природной среды в первую очередь обязан широкомасштабным комплексным междисциплинарным исследованиям археологических памятников [5-8]. Такое сотрудничество способно уточнить палеогеографические, почвенные, растительные, природно-климатические условия среды и организацию хозяйственной деятельности человеческого общества.

Цель работы: изучение современных и палеопочв (разновременных культурных слоев) на археологическом объекте - поселении Калмыковка I, для выявления и реконструкции особенностей древнего почвообразования, его отражения в современных почвах лесостепной зоны Поволжья и адаптации человеческого общества к изменениям окружающей среды.

\section{Методы исследования}

- Метод полевого почвенного и палеопочвенного исследования включал в себя: изучение и сравнение свойств почв поселения и фонового разреза, палеопочв (культурных слоев) и подстилающей грунтовой толщи.

- Неотъемлемой и главной частью полевых почвоведческих и археологических исследований является метод морфологического анализа в выявлении генетических и антропогенно-преобразованных горизонтов. Морфологический метод использовался совместно с картографическим методом для выявления форм неоднородности дневной поверхности и пространственного расположения почвенных горизонтов. В работе применялась нивелирная фиксация древней и современной поверхностей с последующим построением схем разрезов.

- Методы определения физических и химических свойств почв.

\section{Результаты и их обсуждение}

Физико-географическая характеристика района исследований

Поселение эпохи неолита и бронзового века Калмыковка I располагается на правом берегу р. Сок (левый приток среднего течения р. Волги). Район исследований расположен на территории Высокого Заволжья. Почвообразующими породами выступают суглинистые отложения четвертичного периода, в некоторых местах подстилаются отложениями более легкого гранулометрического состава аллювиальноделювиального генезиса. Аллювиальные отложения в долине р. Сок распространены всюду и представлены разнозернистыми песками.

Образование долины р. Сок связано с раннехвалынской трансгрессией Каспийского моря (около 20 тыс. л.н.) [9; 10], что коррелирует с поздневалдайским оледенением на территории Русской равнины [11-13]. В ходе этой трансгрессии были сформированы надпойменные террасы р. Сок. Образование пойменных уровней, а также заложение глубоких меандров и стариц, отчетливо прослеживаемых в рельефе, связано с голоценовыми колебаниями базиса эрозии. В геоморфологическом плане долина р. Сок расположена в пределах неотектонической депрессии, на пологих склонах которой развит сложнопостроенный покров почвенно-делювиальных отложений. Делювиальные отложения всюду представлены суглинками различного состава, а их накопление происходило в течение всей четвертичной эпохи [14]. Русло реки, а также террасы в некоторых местах оказываются врезанными в покров делювия, особенно на участках сужения депрессий.

Интересным оказалось гипсометрическое положение археологического памятника Калмыковка I по отношению к реке. Относительно высокое положение археологического памятника в местах сужения долины, вероятно, связано с высокими половодьями. Как оказалось, в местах сужения долины зачастую располагаются ранненеолитические, энеолитические памятники и селища эпохи бронзы, что, несомненно, связано с изменением условий природной среды. Таким образом, анализ гипсометрического положения разновозрастного памятника Калмыковка I позволяет выявить определенную корреляцию между его местоположением и высотой половодий.

Долина реки Сок представляет собой природноландшафтную зону, где встречается преимущественно луговой тип растительности и почв. Растительный покров территории весьма разнообразен и сочетает в себе лесные и степные участки с преобладанием разнотравно-типчаково-ковыльной степи.

\section{Археологическая характеристика объекта исследования}

Объект археологического наследия «Поселение Калмыковка І» располагался в Красноярском районе Самарской области, в 1 км к востоку от с. Калмыковка. Площадка памятника занимает первую надпойменную террасу правого берега р. Сок, имеет размеры $110 \times 40$ м (примерно 0,4 га) и вытянута по линии С3 - ЮВ, вдоль пониженных форм мезорельефа (старицы реки Сок). Стоянка открыта в 1999 г. А.В. Растороповым [15; 16, с. 202-203]. В $2013-$ 2016 годах археологическим отрядом СГСПУ под руководством К.М. Андреева были определены границы археологического объекта, а также осуществ- 
лены раскопки северо-западной части памятника. Общая вскрытая площадь составила $384 \mathrm{~m}^{2}$. Итоги исследований оперативно введены в научный оборот $[17$, c. $212-219 ; 18$, с. $92-106 ; 19$, с. $130-139 ; 20$, c. $172-180 ; 21$, c. $492-501 ; 22$, c. $143-160]$. В 2014 2015 гг. на памятнике были проведены почвенные исследования.

Площадка памятника на всей исследованной раскопками площади имеет понижение к северу, с перепадом высот до 233-240 см. Максимальная мощность культурного слоя фиксируется на ровном участке вершины первой террасы и составляет 110 120 см, на склоне уменьшается до 40 см. Необходимо отметить, что активная деятельность землероев и, возможно, интенсивная распашка территории на площади памятника привела к «смазанности» его стратиграфии и значительному перемещению находок между слоями, но все же сгруппированность находок и их специфика позволяют вычленить разновременные культурные слои.

Керамическая коллекция стоянки Калмыковка I разделяется на две группы. Первая - проявляет наибольшую близость с керамическими комплексами погребальных и поселенческих памятников срубной культуры позднего бронзового века [23, с. 209-240; 24, с. 152-208]. Вторая - обнаруживает сходство с комплексами средневолжской культуры, относящейся к развитому и позднему периодам развития неолита лесостепного Поволжья [25, с. 177-215; 26, с. 63-139].

Керамическая коллекция стоянки Калмыковка I, относящаяся к эпохе неолита, представлена примерно 400 фрагментами от 70 сосудов, по способу орнаментации она разделяется на четыре типологические группы. Первая группа (19 сосудов) представлена неорнаментированными или украшенными лишь поясками ямок-жемчужин венчиками, вторая группа (23 сосуда) орнаментирована наколами различной формы, третья группа (26 сосудов) украшена оттисками зубчатого и гребенчатого штампа различной формы, наконец, четвертая группа (5 сосудов) - венчики и стенки, орнаментированные преимущественно прочерченными линиями. В радиоуглеродной лаборатории РГПУ им. А.И. Герцена по неолитическим материалам стоянки Калмыковка I было получено три даты по ${ }^{14} \mathrm{C}$. По фрагментам неорнаментированных стенок, технология изготовления которых близка елшанским комплексам, дата середины VI тыс. до н.э.: ( $\mathrm{Spb}$ - 1415) $6643 \pm 110$ ВР (1б 5660-5480 ВС, $2 \sigma 5740-5370$ BC). Еще две даты первой четверти V тыс. до н.э. получены по фрагментам стенок сосуда, орнаментированного оттисками короткого и длинного гребенчатого штампа: (Spb - 1759) $5950 \pm 120 \mathrm{BP}$ ( $1 \sigma 5000-4690$ ВС, 2 $\sigma$ 5250-4500 ВС) и по костям лося, связанным с описанным гребенчатым сосудом:

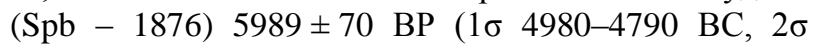
5060-4710 ВС). Приведенные датировки свидетельствуют о неоднократном заселении площадки памятника в неолите.

Керамика срубной культуры представлена 222 крупными и 86 мелкими фрагментами. По венчикам и выразительным фрагментам стенок удалось реконструировать около 30 сосудов баночной и горшковидной формы. Орнамент в основном наносился оттисками короткого, среднего и длинного гребенчатого штампа, реже прочерченными линиями, ямками и насечками. Также к эпохе бронзы, за редким исключением, относится вся остеологическая коллекция памятника. Среди определяемых доминируют кости КРС (47 ед.), в незначительном количестве выявлены кости МРС (7 ед.), лошади (6 ед.) и свиньи/кабана (2 ед.). По фрагментам стенок сосуда срубной куль-

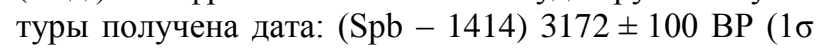
1544-1372 ВС, 2б 1687-1196 ВС). Она характеризует примерное время заселения человеком данной территории в позднем бронзовом веке (третья четверть II тыс. до н.э.).

\section{Почвенная характеристика}

\section{объекта исследования}

На поселении Калмыковка I были изучены современные почвы в раскопе и в фоновом разрезе, разновременные культурные слои и почвообразующие породы. Была изучена южная стенка археологического раскопа поселения, ее ширина составила 16 м, а глубина 1,1 м (рис. 1). Морфологический анализ почв раскопа (разрез 5а-2015) показал стратиграфию профиля, включающего два разновременных культурных слоя (рис. 1).
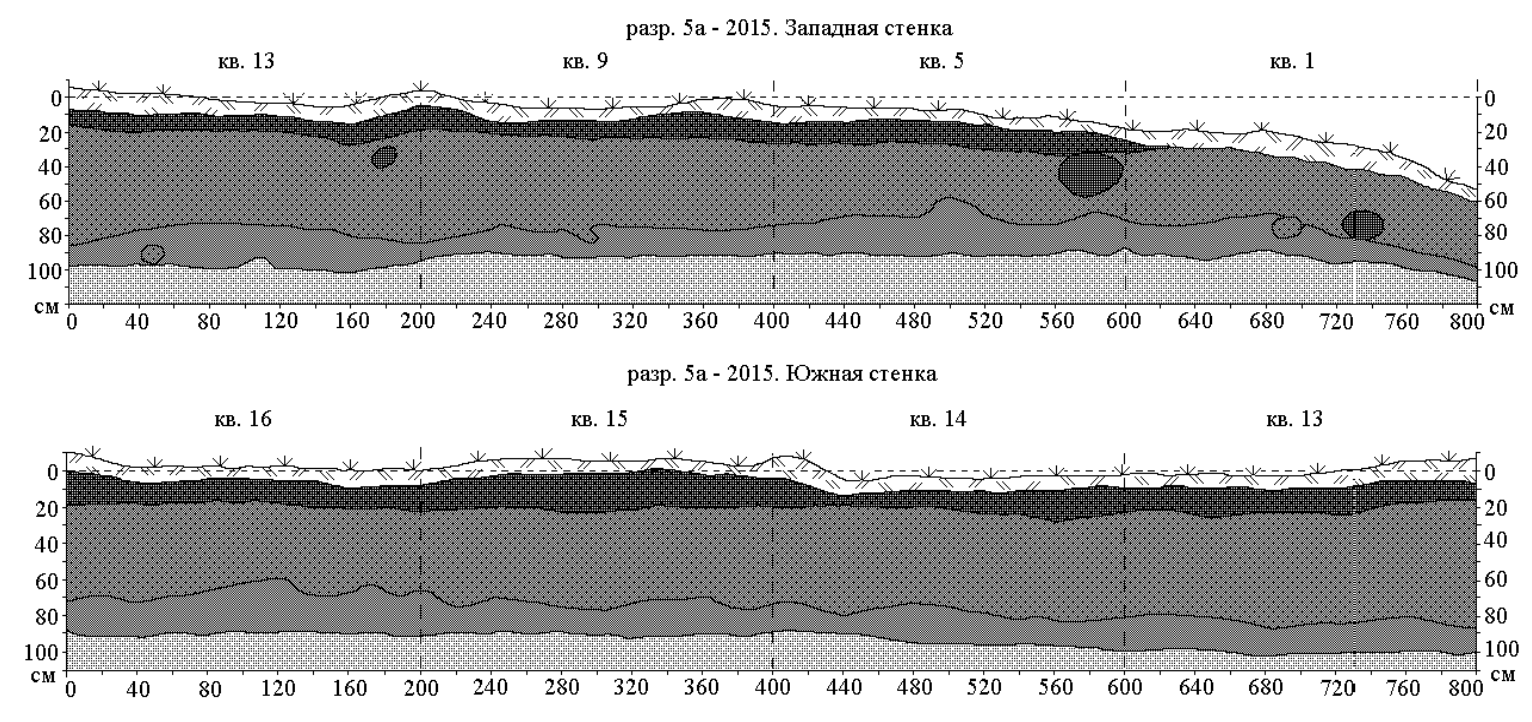

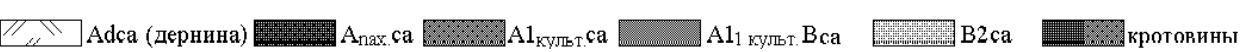

Рисунок 1 - Стратиграфия почвенного профиля разреза 5а-2015.

Поселение Калмыковка I, Красноярский район, Самарская область 
Описание разреза 5а-2015. Археологический раскоп поселения Калмыковка I

Adca 0-5 см. Дернина, очень густая. Светлосерая. Граница ровная, переход заметен по изменению цвета и наличию корней.

Апах.са 5-20 (25) см. Темно-серый, сухой, легкосуглинистый, обильно тонкопористый, в верхней части горизонта наблюдается горизонтальная делимость, обилие точечных включений бурого и охристого цветов, насыщен тонкими корнями травянистой растительности. Встречаются редкие артефакты (в основном фрагменты керамики). Переход неясный, заметен по изменению структуры и границе былой вспашки.

A1 культ.са 20 (25)-80 см. Данный горизонт является археологическим культурным слоем и отнесен к срубной культуре бронзового века. Горизонт очень турбирован мезобиотой (кротовины) и значительно затронут антропогенезом в прошлом. Сухой, порошистый, мелкокомковатый, среднесуглинистый, тонко- и крупнопористый, встречаются мелкие корни травянистой растительности и копролиты, обилие включений бурого цвета размером 1-2 мм (возможно, керамическая крошка). Горизонт насыщен фрагментами керамики. Переход неясный.

A1_В культ.са 80-100 см. Аналогичен вышележащему горизонту, но приобретает буроватый оттенок. Данный горизонт является культурным слоем, но отнесен к развитому неолиту - средневолжской культуре. Горизонт менее пронизан корнями, по сравнению с вышележащим; редкие выраженные кротовины, как правило, вертикальной ориентации, выполненные материалом бурого и серого цветов. Граница ровная, местами нарушенная кротовинами.

В2са 100-112 см (дно). Бурый, свежий, легкосуглинистый, имеет неясно мелкоореховатую структуру, но практически бесструктурный. Горизонт обильно пронизан белесой присыпкой $\mathrm{CO}_{2}$ карбонатов, бурно вскипает от $\mathrm{HCl}$. Редкотонкопористый, встречаются темно-серые стяжения (возможно $\mathrm{Mn}-\mathrm{Fe}$ ). Единичные кротовины горизонтальной ориентации, выполненные материалом бурого и серого цветов. Горизонт уходит в дно разреза.

Почва: чернозем обыкновенный на покровных лессовидных суглинках, биогенно- и антропогеннонарушенный, старопахотный [27; 28].

Для сравнения свойств почв был заложен фоновый разрез (разрез 6а-2015) в 50 м к югу от раскопа поселения вглубь водораздельной поверхности. Описание разреза в работе не приводится. Морфологический анализ показал, что в фоновом разрезе сформирован чернозем обыкновенный на покровных лессовидных суглинках, старопахотный. [27; 28]. Профиль почвы фонового разреза по морфологии и стратиграфии практически идентичен профилю почвы в археологическом раскопе. Одним из существенных различий является то, что почва археологического раскопа сильно турбирована (мезобиотой и затронута антропогенезом) и имеет более вытянутый гумусовый профиль. Предположительно последнее может быть связано с деятельностью человека (наличие двух разновременных культурных слоев, распаханность территории) и припойменной частью террасы.
Физические и физико-химические свойства почв поселения Калмыковка I

После отбора образцов из каждого горизонта в двух разрезах был выполнен анализ физических свойств почв. По гранулометрическому составу почвы археологического раскопа поселения (разрез 5а2015) и почвы фонового разреза (6а-2015) относятся к средним и легким суглинкам по классификации Н.А. Качинского [29]. Заметно преобладает фракция тонкого песка, следующей по содержанию является фракция крупной пыли. Фракция мелкого песка в профилях почв распределяется равномерно, с преобладанием в верхней части профиля в разрезе археологического раскопа, и в средней части профиля - в фоновом разрезе.

Относительно легкий гранулометрический состав свидетельствует, вероятно, о периодическом колебании уровня р. Сок в прошлые эпохи, о чем также свидетельствует залегание одного культурного слоя на другом, но культурный слой эпохи бронзы располагается на некотором удалении от реки по сравнению с неолитическим культурным слоем. Как нам кажется, изменение русла и уровня реки вынуждало человека по-разному организовывать поселения в разные эпохи (в древности люди были вынуждены переносить поселение в глубь водораздельной поверхности).

Дополнительно были определены некоторые физико-химические показатели почв [30-34]. По распределению гумуса почвы раскопа и фонового разреза практически схожи, но все-таки различаются (рис. 2).

В почве раскопа в верхней части гумусового горизонта (подгоризонте Adca) содержание гумуса составляет $7,02 \%$, затем содержание его постепенно снижается с глубиной. В почве фонового разреза содержание гумуса составляет 7,4\%, снижение с глубиной происходит менее заметно, чем в почве раскопа; в средней части гумусовых подгоризонтов его распределение практически равномерное 5-6\%, а уменьшение значений наблюдается уже в переходных к почвообразующей породе горизонтам. Обращает на себя внимание тот факт, что содержание гумуса и в подгумусовой части профиля почвы фонового разреза несколько выше, чем в почве археологического раскопа, что в последнем, по-видимому, связано с антропогенезом и с изменением русла реки. Вероятно, при высоких половодьях территория, на которой располагалось поселение, подтапливалась, смывая органический материал (краевая часть террасы).

Разница в отношении кислотности между почвами раскопа и фонового разреза практически не видна (рис. 2). Все значения находятся в слабощелочной реакции среды, и только почва раскопа к нижним горизонтам приобретает более щелочной диапазон. Распределение содержания $\mathrm{CO}_{2}$ карбонатов в обеих почвах имеет разный характер, но напрямую связан с $\mathrm{pH}$ (рис. 2).

Поглощенные основания в почвах (рис. 2) распределены очень неравномерно. Кривые распределения по профилю поглощенных $\mathrm{Ca}^{2+}$ и $\mathrm{Mg}^{2+}$ в почве раскопа имеют разнонаправленный (зеркальный) характер, приуроченный именно к культурным слоям, тогда как в почве фонового разреза имеет место быть естественное распределение поглощенных основа- 
ний. Такой характер распределения элементов в очередной раз маркирует и подчеркивает залегание разновременных культурных слоев, то есть, несомненно, специфика распределения элементов по профилю определена человеческой деятельностью в прошлые эпохи. Такая закономерность в распределении элементов, но в меньшей степени выраженности, была зафиксирована на других археологических объектах, расположенных в Самарском и Саратовском Заволжье.
Обменный $\mathrm{Na}^{+}$(рис. 2) в обеих почвах практически отсутствует, только в почве раскопа он иллювиируется в нижележащие горизонты. Обменный $\mathrm{K}^{+}$ (рис. 2) в обеих почвах имеет низкие значения. В почве раскопа его распределение элювиальное, в почве фонового разреза - элювиально-иллювиальное.

В обеих почвах низкое содержание $\mathrm{P}_{2} \mathrm{O}_{5}$ и распределение его практически схожее, а вот распределение $\mathrm{K}_{2} \mathrm{O}$ в почвах связано с антропогенной деятельностью (рис. 2).

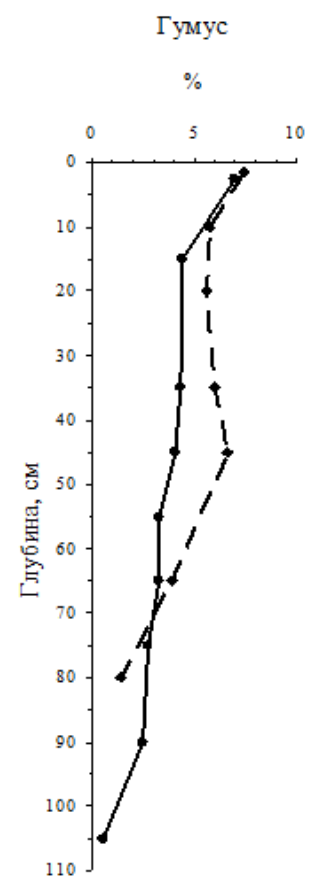

$\mathrm{Na}^{+}$

мг-9кв./ 100 г почвы

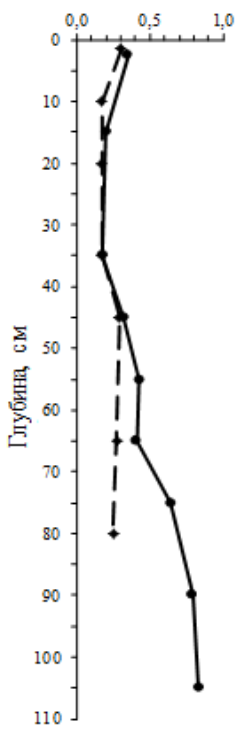

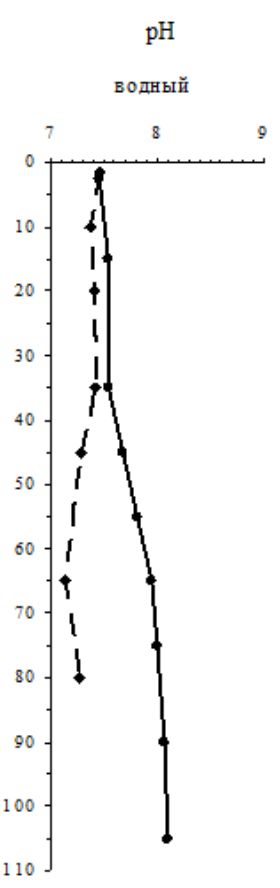

$\mathrm{K}^{+}$

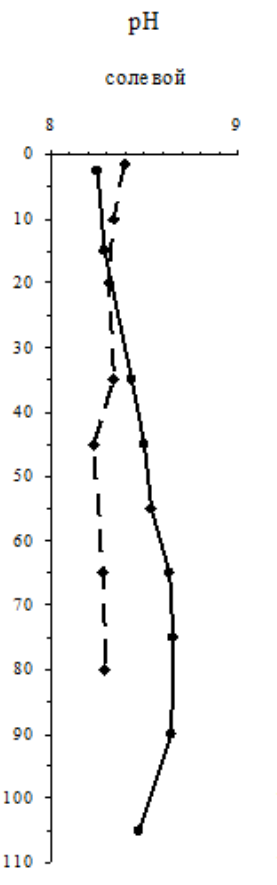

$\mathrm{P}_{2} \mathrm{O}_{5}$
$\mathrm{Ca}^{++}$

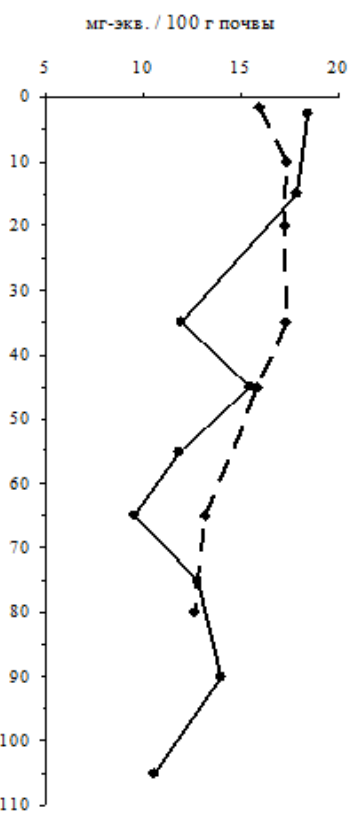

$\mathrm{K}_{2} \mathrm{O}$

мг/ 100 г почвы

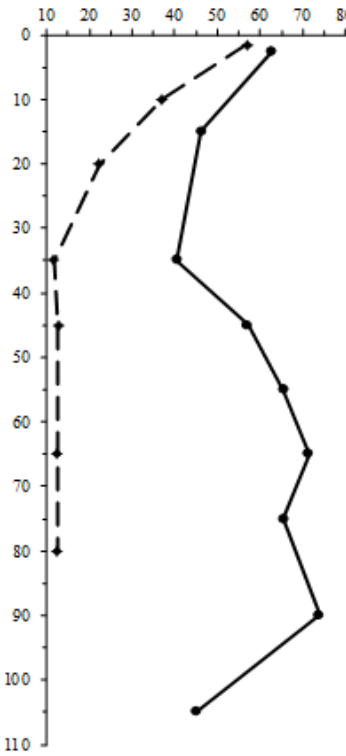

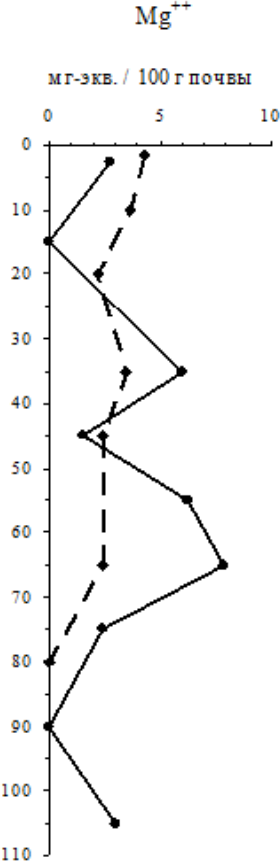

$\mathrm{CO}_{2}$ карбонат ов
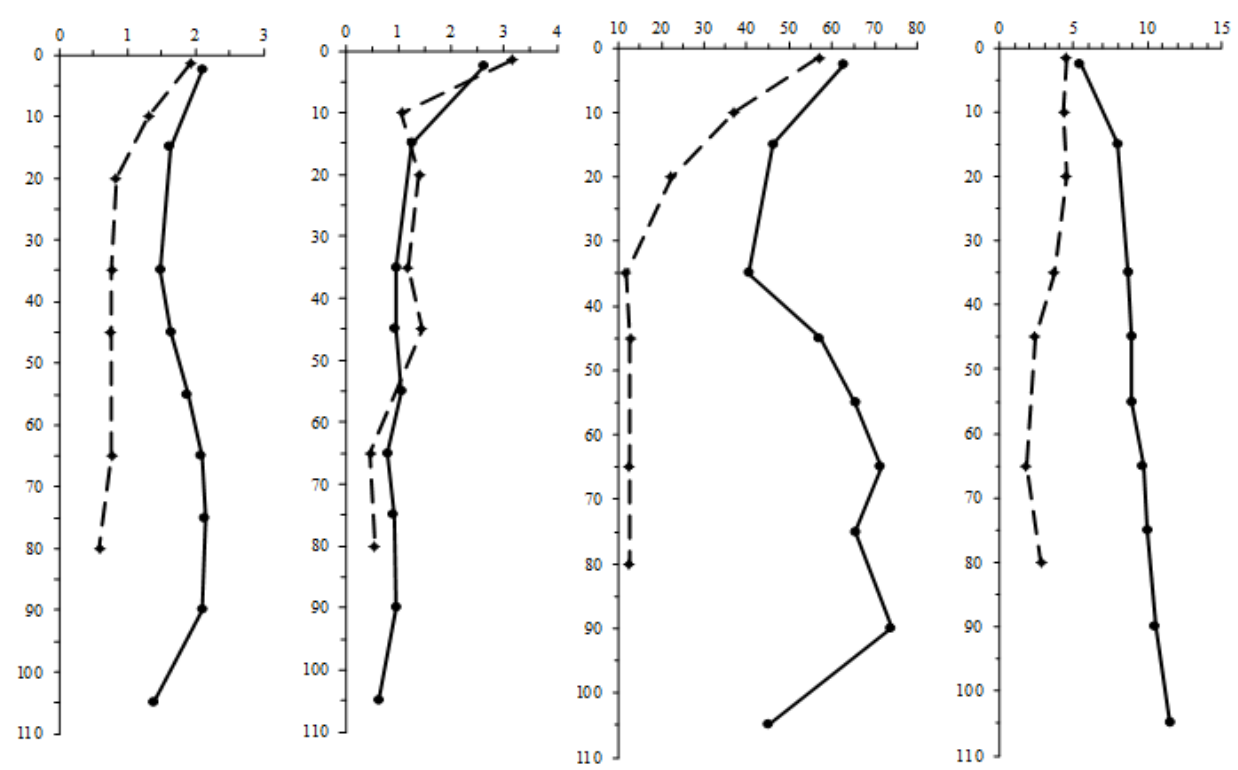

$\longrightarrow$ разрез 5a-2015

_. - разрез 6a-2015

Рисунок 2 - Физико-химические свойства почв разрезов 5а-2015 и 6а-2015 (фон).

Поселение Калмыковка I, Красноярский район, Самарская область

\section{Заключение}

На поселении Калмыковка I зафиксированы два разновременных культурных слоя (залегающие непрерывно один на другом), датированные по арте- фактам: эпохой неолита (VI-V тыс. до н.э.) и бронзовым веком (II тыс. до н.э.). Выявлено различие почв, обусловленное интенсивной антропогенной преобразованностью в среднем и позднем голоцене, что под- 
тверждается радиоуглеродными датировками культурных слоев. Профиль почвы археологического раскопа по морфологии и стратиграфии практически не отличается от профиля почвы в фоновом разрезе, но все же одним из существенных различий является то, что почва археологического раскопа сильно турбирована (мезобиотой и затронута антропогенезом), в связи с чем имеет более вытянутый гумусовый профиль. Предположительно последнее может быть связано с деятельностью человека (наличие пахотного горизонта, а также наличие двух разновременных культурных слоев) и припойменной частью террасы, где располагалось поселение.

Физические свойства почв, в частности, гранулометрический состав приобретает более легкие фракции в направлении от водораздела к речным террасам и склонам. Такая закономерность зафиксирована на ключевом участке грунтового могильника эпохи раннего энеолита Екатериновский мыс (Безенчукского района Самарской области) [8] и на других объектах, изученных в Среднем Поволжье. Вероятно, за счет меандрирования русел и изменения уровня рек во времени изменяется и гранулометрический состав прирусловых территорий. С этими же процессами связано и содержание гумуса в почвах на прирусловых территориях. Во время половодий усиливались процессы склонового смыва, и содержащийся в почве гумус, в краевых зонах поселений, попросту выносился вместе с минеральной массой.

\section{Список литературы:}

1. Изменение климата и ландшафтов за последние 65 миллионов лет (кайнозой: от палеоцена до голоцена) / под ред. профессора А.А. Величко. М.: ГЕОС, 1999. $260 \mathrm{c}$.

2. Палеопочвы как индикаторы эволюции биосферы. М.: НИА Природа, 2007. 282 с.

3. Van Vliet-Lanoe et al. Palaeogeographic evolution of northwestern Europe during the Upper Cenozoic // Geodiversitas. 2002. Vol. 24 (3). P. 511-541.

4. Svendsen J.I., Alexanderson H., Astakhov V.I. et al. Late Quaternary ice sheet history of northern Eurasia // Quaternary Science Reviews. 2004. Vol. 23. P. 1229 1271.

5. Демкин В.А. Палеопочвоведение и археология: интеграция в изучении истории природы и общества. Пущино, 1997. 213 с.

6. Гугалинская Л.А., Алифанов В.М., Березина Н.С., Березин А.Ю., Хисяметдинова А.А., Попов Д.А., Вагапов И.М., Овчинников А.Ю., Кондрашин А.Г., Рапацкая К.М. Палеоэкология почвообразования на финальнопалеолитическом поселении Шолма-I (Приволжская возвышенность, Чувашское плато) // Известия Самарского научного центра РАН. 2010. Т. 12, № 1 (4). C. 1006-1010.

7. Иванов И.В., Александровский А.Л., Макеев А.О. и др. Эволюция почв и почвенного покрова. Теория, разнообразие природной эволюции и антропогенных трансформаций почв / отв. ред. В.Н. Кудеяров, И.В. Иванов. М.: ГЕОС, 2015. 925 с.

8. Овчинников А.Ю., Алифанов В.М., Королев А.И. Почвы могильника Екатериновский мыс в Среднем Поволжье // Проблемы региональной экологии. 2017. № 3. C. $65-71$.

9. Свиточ А.А., Янина Т.А. Будущее Каспия - в его прошлом // Природа. 1996. № 2. С. 45-57.
10. Янина Т.А. Палеогеография бассейнов ПонтоКаспия в плейстоцене по результатам малакофаунистического анализа: автореф. дис. ... д-ра геогр. наук. М., 2009. 42 с.

11. Болиховская Н.С., Молодьков А.Н. Корреляция лёссово-почвенной формации и морских отложений Северной Евразии (по результатам палинологического и ЭПР анализов) // Проблемы палеогеографии и стратиграфии плейстоцена. М.: Изд-во Моск. ун-та, 2000. С. 149-178.

12. Болиховская Н.С., Молодьков А.Н. Схема периодизации, корреляция и возраст климатических событий плейстоцена // Фундаментальные проблемы квартера: итоги изучения и основные направления дальнейших исследований: материалы VI всерос. совещания по изучению четвертичного периода. Новосибирск, 2009. С. 75-78.

13. Molodkov A.N., Bolikhovskaya N.S. Long-term palaeoenvironmental changes recorded in palynologically studied loess-palaeosol and ESR-dated marine deposits of Northern Eurasia: implication for sea-land correlation // Quaternary International. 2006. № 152-153. P. 37-47.

14. Экологический аспект в составе «Положений о территориальном планировании Самарской области». Самара: ТеррНИИгражданпроект, 2006. 50 с.

15. Расторопов А.В. Отчет об археологической разведке в Красноярском районе Самарской области Расторопова Александра Васильевича по Открытому листу № 220 форма № 2, выданному 24 мая 1999 г. Красный Яр, 2000 // Архив ИА РАН.

16. Расторопов А.В. Разведки в Красноярском районе Самарской области // Археологические открытия 1999 года. М.: Изд-во ИА РАН, 2001. С. 202-203.

17. Андреев К.М., Выборнов А.А., Васильева И.Н. Неолитический комплекс стоянки Калмыковка I // Известия СНЦ РАН. 2015. Т. 17, № 3. С. 212-219.

18. Андреев К.М., Выборнов А.А. Поселение Калмыковка I (некоторые итоги исследований 20132014 годов) // Самарский край в истории России: материалы межрегион. науч. конф., посв. 190-летию со дня рождения П.В. Алабина. Вып. 5. Самара: Изд-во СОИКМ, 2015. С. 92-106.

19. Андреев К.М., Выборнов А.А., Васильева И.Н., Сомов А.В. Новые неолитические материалы стоянки Калмыковка I // Известия СНЦ РАН. 2016. Т. 18, № 3. С. 130-139.

20. Андреев К.М., Выборнов А.А., Васильева И.Н., Сомов А.В. Неолитические материалы стоянки Калмыковка I // Известия Самарского научного центра PAH. 2017. Т. 19, № 3. С. 172-180.

21. Андреев К.М., Выборнов А.А. Комплекс позднего бронзового века поселения Калмыковка I // Вопросы археологии Поволжья. Вып. 6. Самара: ООО «Книжное издательство», 2017. С. 492-501.

22. Андреев К.М., Выборнов А.А., Васильева И.Н. Стоянка Калмыковка I - новый памятник неолита лесостепного Поволжья // Тверской археологический сборник. Вып. 11. Тверь: Изд-во «Триада», 2018. С. $143-160$.

23. Седова М.С. Поселения срубной культуры // История Самарского Поволжья с древнейших времен до наших дней. Бронзовый век. Самара: Изд-во СНЦ PAH, 2000. C. 209-240.

24. Семенова А.П. Погребальные памятники срубной культуры // История Самарского Поволжья с древнейших времен до наших дней. Бронзовый век. Самара: Изд-во СНЦ РАН, 2000. С. 152-208. 
25. Выборнов А.А. Средневолжская культура // История Самарского Поволжья с древнейших времен до наших дней. Каменный век. Самара: Изд-во СНЦ PAH, 2000. C. 177-215.

26. Выборнов А.А. Неолит Волго-Камья. Самара: Изд-во СГПУ, 2008. 490 с.

27. Классификация и диагностика почв СССР. М.: Колос, 1977. 224 c.

28. Классификация и диагностика почв России. Смоленск: Ойкумена, 2004. 342 с.

29. Качинский Н.А. Методы механического и микроагрегатного анализа почвы. М.: Издательство АН CCCP, 1943. $45 \mathrm{c}$.

30. Агрохимические методы исследования почв. M., 1965. 436 c.

31. Аринушкина Е.В. Руководство по химическому анализу почв. М.: Изд-во МГУ, 1970. 487 с.
32. Вадюнина А.Ф., Корчагина 3.А. Методы исследования физических свойств почв и грунтов. М.: Высшая школа, 1973. 399 с.

33. Теория и практика химического анализа почв / под ред. Л.А. Воробьевой. М.: ГЕОС, 2006. 400 с.

34. Воробьева Л.А., Ладонин Д.В., Лопухина О.В., Рудакова Т.А., Кирюшин А.В. Химический анализ почв. Вопросы и ответы. М., 2012. 186 с.

Статья публикуется при частичной поддержке гранта РФФИ, проект № 17-04-00078-а. Работа подготовлена в рамках выполнения Государственного задания Минобрнауки РФ: проект № 33.1907.2017/ПЧ «Традиционные и инновационные модели развития древнего населения Поволжсья", проект № AAAA-A18-118013190175-5 «Развитие почв в условиях меняющегося климата и антропогенных воздействий».

\title{
SOIL-ARCHAEOLOGICAL CHARACTERISTIC \\ OF THE ARCHAEOLOGICAL SETTLEMENT KALMYKOVKA I IN THE SAMARA VOLGA REGION
}

(C) 2018

Ovchinnikov Andrey Yurievich, candidate of biological sciences, senior researcher of Soil Ecology Laboratory Institute of Physicochemical and Biological Problems of Soil Science of Russian Academy of Sciences (Pushchino, Moscow Region, Russian Federation)

Andreev Konstantin Mikhailovich, candidate of historical sciences, associate professor of Domestic History and Archeology Department

Samara State University of Social Sciences and Education (Samara, Russian Federation)

\begin{abstract}
The paper publishes the results of soil research on the archaeological site - the settlement of the Neolithic and Bronze age Kalmykovka I located in the Krasnoyarsk district of the Samara Region. The paper briefly describes the archaeological site. Its cultural identity and the absolute age of the found artifacts are indicated. The morphological studies and analysis of the physical and the chemical properties of the modern soils, soil-forming rocks and cultural archaeological layers were carried out at the key site The taxonomic difference in soils was identified, related to the anthropogenic transformation of the soil in the middle and late Holocene. The physical properties of soils, and in particular, the granulometric composition, acquire lighter fractions in the direction from the watershed to the river terraces and slopes. Such pattern is recorded on other archaeological sites in the Middle Volga Region. The meandering of riverbed and the change in the level of rivers at different time intervals of the Holocene leaded to a change in the granulometric composition of the territory of the riverbed and river terrace. The preliminary results showed that an ancient man accounted for: a geographical location, a landscape exposure, the riverbed and the river level while arranging the settlement Kalmykovka I in different periods of the Holocene. The change in the paleogeographic situation on the given territory from the Middle Holocene to the Late one apparently influenced the river level content of the Sok River and its riverbed, which forced the generations of people to move the settlement deep into the watershed surface.

Keywords: pedology; archeology; paleopedology; paleogeography; paleoecology; stratigraphy; archaeological settlement; archaeological layers; pedogenesis; soil profile; soil morphology; physico-chemical properties of soil; Holocene; Neolithic; Middle Volga culture; Late Bronze Age; srubnaya culture; absolute chronology; Middle Volga Region.
\end{abstract}

УДК $902.01(902.64)$

Статья поступила в редакцию 04.06.2018

\section{К ВОПРОСУ О ВРЕМЕНИ И ИСТОКАХ ГОНЧАРНЫХ ТРАДИЦИЙ В РАННЕМ НЕОЛИТЕ ЕВРОПЕЙСКОГО СЕВЕРА РОССИИ}

(C) 2018

\author{
Иванищева Марина Викторовна, начальник \\ Восточно-Прионежская археологическая экспедиция (2. Вологда, Российская Федерация)
}

Аннотация. В настоящее время превалирует стадиальная схема развития орнаментальных стилей в ранненеолитических древностях лесной полосы Европейской части России - от неорнаментированной/накольчатой к более поздней гребенчатой орнаментальной традиции. Среди серий дат, принятых как хронологический репер для неолита лесной полосы около 7000 л.н., имеются более глубокие/древние определения как для накольчатых/неорнаментированных фрагментов, так и для сосудов с гребенчатым стилем орнаментации. Новые глубокие радиоуглеродные определения для керамических комплексов зауральских/западносибирских памятников позволяют рассматривать данные «отклонения» не как погрешность метода или неточность интерпретации полевых материалов, а видеть в них отражение самых ранних «потоков» неолитизации, следы 